\title{
Production of biosurfactant by Wickerhamomyces anomalus PY189 and its application in lemongrass oil encapsulation
}

\author{
Chanapa Dejwatthanakomol $^{\mathrm{a}}$, Jirarat Anuntagool ${ }^{\mathrm{b}}$, Masaaki Morikawa ${ }^{\mathrm{c}}$, Jiraporn Thaniyavarn ${ }^{\mathrm{a}, *}$ \\ a Department of Microbiology, Faculty of Science, Chulalongkorn University, Bangkok 10330 Thailand \\ b Department of Food Technology, Faculty of Science, Chulalongkorn University, Bangkok 10330 Thailand \\ c Graduate School of Environmental Science, Hokkaido University, Japan
}

*Corresponding author, e-mail: jiraporn.th@chula.ac.th

Received 11 Jun 2015

Accepted 8 Aug 2016

\begin{abstract}
In this study, the production and characterization of a biosurfactant from yeast Wickerhamomyces anomalus strain PY189 was carried out. The highest efficiency for biosurfactant production was found when the organism was grown in a medium containing $4 \%(\mathrm{v} / \mathrm{v})$ soya bean oil and $0.4 \%(\mathrm{w} / \mathrm{v}) \mathrm{NaNO}_{3}$ at $30^{\circ} \mathrm{C}$ and $\mathrm{pH} 5.5$ for 7 days. After 7 days of cultivation, $W$. anomalus PY189 was able to produce up to $0.57 \mathrm{~g} / \mathrm{l}$ of biosurfactant as ethyl acetate extracts. The culture supernatant was able to reduce the surface tension of the culture broth from $42.5 \mathrm{mN} / \mathrm{m}$ to $36.5 \mathrm{mN} / \mathrm{m}$ with a critical micelle concentration of $204 \mathrm{mg} / 1$. The crude extract of biosurfactants was then applied to the encapsulation of lemongrass oil. Emulsions of lemongrass oil in $20 \mathrm{mg} / \mathrm{dl}$ maltodextrin solution (oil:maltodextrin solution ratios of $0.2: 1,0.15: 1$, and $0.1: 1)$ containing $0.8 \%$ and $1 \%(\mathrm{w} / \mathrm{v})$ crude biosurfactant extract were stable for at least $24 \mathrm{~h}$ and had an average oil droplet size of less than $10 \mu \mathrm{m}$. Lemongrass oil microcapsules were later produced using a spray drying technique. This microcapsule exhibited microbial growth inhibition activity against E. coli, S. aureus, and Salmonella at 5\% (w/v) concentration.
\end{abstract}

KEYWORDS: emulsifier, sophorolipid, microencapsulation

\section{INTRODUCTION}

Biosurfactants (or bioemulsifiers) are surface-active compounds from biological sources, usually produced by bacteria, yeast, or fungi. They are amphiphatic molecules consisting of a hydrophilic and a hydrophobic domain and capable of reducing surface and interfacial tension at the interface between liquids, solids, and gases. They have advantages over their chemical counterparts in biodegradability and extreme temperature or $\mathrm{pH}$ and in having lower toxicity to animals ${ }^{1}$. Biosurfactants may have one of the following structures: glycolipid, polysaccharidelipid complex, lipoprotein or lipopeptide, or phospholipid. The most commonly isolated and widely studied group of surfactants produced by microorganism is glycolipids. Glycolipids are carbohydrates in combination with long-chain fatty acid. The best known glycolipids are trehalolipids, sophorolipids and rhamnolipids ${ }^{2}$. They possess good surface active properties and show excellent compatibility with human skin, a property that is very important for cosmetic and personal care applications. Furthermore, they can be used in various other sectors due to their emulsifying, antimicrobial, and other beneficial properties ${ }^{3}$. Sophorolipids can be synthesized in high concentrations by nonpathogenic yeasts. This fact makes sophorolipids particularly attractive for further commercial production and use.

Wickerhamomyces anomalus (Pichia anomala, Kurtzman et al) ${ }^{4}$, one of the nonpathogenic yeast, has been isolated from various environments and has shown remarkable physiological robustness towards chemical, physical and biological stresses, such as extreme $\mathrm{pH}$ or water activity ${ }^{5}$. It produces a number of killer proteins, including beta1,3-glucanase, with different glycosylation showing antimicrobial activities against not only bacteria but also yeast and filamentous fungi. Killer proteins are also useful matrix for generating and producing anti-idiotypic antibodies killing microorganisms and even viruses ${ }^{6}$. These features make $W$. anomalus a valuable microbial agent for improving feed and food safety during preservation and antimicrobial therapies in human and animals ${ }^{7}$. Moreover, it has been reported that $W$. anomalus has flavour enhancing effect in food and beverage fermentation ${ }^{8,9}$. 
We have previously reported that $W$. anomalus PY1, a thermo-tolerant strain isolated from fermented food, is a sophorolipid producer which can produce sophorolipids in a wide range of temperature (20$\left.40^{\circ} \mathrm{C}\right)^{10}$. Enhanced production of sophorolipids by PY1 or its derivative strains is thus expected to be useful for improvement of preservation and value of foods.

Emulsifiers play an important role in forming the desirable consistency and texture as well as in phase dispersion to stabilize emulsions ${ }^{11}$. The quality of a vast number of food products relies on the emulsification ability of synthetic emulsifiers. With an increasing consciousness among consumers, a steady increase in demand for more natural food ingredients and additives is observed. Biosurfactants produced by nonpathogenic yeast are a promising natural ingredient that can be used to produce many food products and additives including microcapsules which are to be used for preservation in food experiencing minimal process. Microbial contamination in minimally processed food is a major problem for public health. If not preserved by refrigeration, other methods must be used to prevent microbial growth in such food product. Essential oils from various edible plants, a natural ingredient, are reported to exhibit various biological activities including bacterial inhibition. It has been reported that the essential oils from herbaceous plant, such as citronella (Cymbopogon nardus), lemongrass (C. citratus $)^{12}$, basil (Ocimum basilicum) ${ }^{13}$, and plants in the ginger family, are capable of controlling the growth of microorganisms in food ${ }^{14}$

Many active agents present in essential oils are unstable compounds. The activity can reduce over storage time due to oxidation or volatilization. Microencapsulation is a mean to retain their activity. Essential oil microencapsulation can be done using methods such as spray-drying. Studies on lemongrass (C. citratus) essential oil in food and pharmaceutical applications have been reported. Lemongrass essential oil, due to its broad-spectrum antimicrobial activity, was microencapsulated by simple coacervation method that did not deteriorate the essential oil ${ }^{15}$

This study is divided into two parts. The first part aims to determine the optimum condition for the production of biosurfactants from yeast $W$. anomalus strain PY189 and to characterize the yielded crude biosurfactant extract. The second part aims to investigate the application of biosurfactant extract in the production of antimicrobial microcapsules containing lemongrass oil.

\section{MATERIALS AND METHODS}

\section{Microorganisms}

W. anomalus PY189, a biosurfactant hyperproducing mutant strain by EMS from $P$ anomala PY1, was obtained by EMS mutagenesis. The microorganisms were maintained at $5-8^{\circ} \mathrm{C}$ on yeast malt agar (YM) slants containing (w/v) $0.3 \%$ yeast extract, $0.3 \%$ malt extract, $0.5 \%$ Bacto peptone, $1 \%$ glucose and $2 \%$ agar.

\section{Carbon source for biosurfactant production}

Cell culture $(10 \% \mathrm{v} / \mathrm{v})$ of $W$. anomalus PY189 was prepared as inoculum in YM broth at $\mathrm{pH} 4.5$ and incubated at $30^{\circ} \mathrm{C}$ while shaking at $200 \mathrm{rpm}$ for $18 \mathrm{~h}$. The biosurfactant was produced by cultivation of $W$. anomalus PY189 in $50 \mathrm{ml}$ production medium containing (w/v) $0.02 \% \mathrm{KH}_{2} \mathrm{PO}_{4}, 0.02 \%$ $\mathrm{MgSO}_{4} \cdot 7 \mathrm{H}_{2} \mathrm{O}, 0.4 \% \mathrm{NaNO}_{3}, 0.1 \%$ yeast extract and $4 \%$ of various carbon sources, which were glucose $(w / v)$, sucrose $(w / v)$, soya bean oil $(v / v)$, palm oil $(\mathrm{v} / \mathrm{v})$ and coconut oil $(\mathrm{v} / \mathrm{v})$. The culture was placed in a 250-ml Erlenmeyer flask while shaking at $200 \mathrm{rpm}$ for 7 days at $30^{\circ} \mathrm{C}$. Aliquots of the culture were periodically removed to determine growth, and supernatants were kept to determine biosurfactant activity. Growth was measured in terms of dry cell mass. To determine the optimum concentration of the carbon source, concentrations up to $8 \%$ of the selected carbon source were used.

\section{Nitrogen source for biosurfactant production}

Cell culture $(10 \% \mathrm{v} / \mathrm{v})$ of PY189 was prepared as inoculum in YM broth at $\mathrm{pH} 4.5$ and incubated at $30^{\circ} \mathrm{C}$ while shaking at $200 \mathrm{rpm}$ for $18 \mathrm{~h}$. The biosurfactant was produced by cultivation of W. anomalus PY189 in $50 \mathrm{ml}$ production medium containing $0.02 \% \mathrm{KH}_{2} \mathrm{PO}_{4}, 0.02 \% \mathrm{MgSO}_{4} \cdot 7 \mathrm{H}_{2} \mathrm{O}$, $0.1 \%$ yeast extract, $4 \%(\mathrm{v} / \mathrm{v})$ soya bean oil and $0.4 \%(\mathrm{w} / \mathrm{v})$ of various nitrogen sources, which were $\mathrm{NaNO}_{3},\left(\mathrm{NH}_{4}\right)_{2} \mathrm{SO}_{4}$, and $\mathrm{NH}_{4} \mathrm{NO}_{3}$. The culture was placed in a 250-ml Erlenmeyer flask while shaking at $200 \mathrm{rpm}$ for 7 days at $30^{\circ} \mathrm{C}$. Aliquots of the culture were periodically removed for growth determination, and supernatants were used to determine biosurfactant activity. To determine the optimum concentration of the nitrogen source, $0-0.5 \%$ of selected nitrogen source were used.

\section{Determination of biosurfactant activity}

Biosurfactant activity was determined using oil displacement test. Fifty millilitres of distilled water was added to a large Petri dish (15 cm diameter) 
followed by the addition of $15 \mu \mathrm{l}$ of synthetic oil to the surface of water followed by $10 \mu \mathrm{l}$ of culture broth supernatant. The diameter of clear zones from triplicate assays of the same sample was determined $^{16}$. Surface tension was determined by the $\mathrm{Du}$ Nouy ring method ${ }^{17}$ using a Tensiometer (K6, Kruss, Hamburg, Germany). Both oil displacement activity and surface tension were used as criteria to select the condition for $W$. anomalus PY189 cultivation. Critical micelle concentration (CMC) of the biosurfactant was determined ${ }^{18}$.

\section{Production and extraction of biosurfactant}

Biosurfactant production was analysed in 21 of production medium with $4 \%$ soya bean oil as the carbon source, $\mathrm{pH}$ 5.5, shaken at $200 \mathrm{rpm}$ for 7 days at $30^{\circ} \mathrm{C}$. After 7 days, cells were removed by centrifugation at $10000 \mathrm{~g}$ for $15 \mathrm{~min}$. The supernatants were kept at $4{ }^{\circ} \mathrm{C}$ overnight. The oil was removed by hexane extraction. The aqueous phase was then extracted 3 times with ethyl acetate. The solvent layer was evaporated to dryness in a vacuum at $40^{\circ} \mathrm{C}$. The crude extracts were obtained and the structural characteristics and CMC were determined ${ }^{18}$. Crude extract was dissolved in $50 \mathrm{mM}$ Tris- $\mathrm{HCl}$ buffer $\mathrm{pH} 8.0$, serially diluted within the range of $0.1-1000 \mathrm{mg} / 1$, and the surface tension was then measured. The CMC values were determined by plotting the surface tension values against the log of biosurfactant concentrations.

\section{Thin layer chromatography of biosurfactants}

Crude extracts, prepared as described above, were dissolved in ethyl acetate and analysed by TLC on gel plates. The samples were then resolved in chloroform:methanol:water $(65: 25: 4 \mathrm{v} / \mathrm{v})$, and visualized with iodine vapour and Molisch reagent for lipid and carbohydrate detection, respectively.

\section{Emulsification of lemongrass oil}

Solutions of biosurfactant in maltodextrin solution (20 $\mathrm{mg} / \mathrm{dl}$ ) were prepared at various concentrations of biosurfactant $(0.6 \%, 0.8 \%$ and $1 \%$ by weight). Lemongrass (C. citratus) oil was added into the solutions at oil:maltodextrin solution ratios of $0.2: 1$, $0.15: 1$, and $0.1: 1$. The solution was then homogenized with a hand homogenizer at $19000 \mathrm{rpm}$ for $5 \mathrm{~min}$. Then homogenized solution $(10 \mathrm{ml})$ was pipetted into a test tube and let stand for $24 \mathrm{~h}$ at room temperature. The emulsion that showed no separation was chosen for the production of microcapsule using spray drying technique.

\section{Microencapsulation}

Total oil content of the powder was determined by the method modified from that of Hogan et $\mathrm{al}^{19}$. Total oil was determined by gently shaking $2 \mathrm{~g}$ of powder with $250 \mathrm{ml}$ petroleum ether in a sealed $500 \mathrm{ml}$ glass bottle at $30^{\circ} \mathrm{C}, 200 \mathrm{rpm}$ for $6 \mathrm{~h}$. The solvent was filtered through Whatman filter paper. The extracted oil in the filtrate was determined gravimetrically following the removal of solvent by rotary evaporation and oven drying at $50^{\circ} \mathrm{C}$ for $2 \mathrm{~h}$. The extractable oil was determined by gently shaking $2 \mathrm{~g}$ of powder with $250 \mathrm{ml}$ petroleum ether at $30^{\circ} \mathrm{C}$, and $200 \mathrm{rpm}$ for $15 \mathrm{~min}$. Microencapsulation efficiency (ME) was calculated as follows:

$$
\mathrm{ME}=1-(\text { extractable oil }) /(\text { total oil }) .
$$

One thousand millilitres of lemongrass oil emulsion was sprayed dried at $25 \pm 5 \mathrm{ml} / \mathrm{min}$ with the inlet air temperature of $180^{\circ} \mathrm{C}$. The dried microcapsules were packaged in an aluminium foil laminated pouch for further analyses.

A small amount of microcapsules were observed using a scanning electron microscope in order to determine the particle size and to observe particle morphology.

\section{Minimum inhibitory concentration of microcapsule}

MIC of lemongrass oil and microcapsule were determined using the agar dilution method. S. aureus, E. coli, and Salmonella sp. were grown in nutrient agar at $37^{\circ} \mathrm{C}$ for $24 \mathrm{~h}$. The microorganisms were inoculated in Müller-Hinton broth (w/v, 30\% beef infusion, $2 \%$ casein hydrolysate and $0.15 \%$ starch, $\mathrm{pH}$ adjusted to neutral at $25^{\circ} \mathrm{C}$ ) and incubated at $37^{\circ} \mathrm{C}$ for 18-24 h (density $10^{8} \mathrm{CFU} / \mathrm{ml}$ ). Lemongrass oil and microcapsule were prepared at different concentrations and then transferred into Müller-Hinton agar (MHA) contained 0.5\% Tween 20. MHA was allowed to solidify in a Petri dish. Two microlitres of microorganism was dropped on the surface of MHA and incubated at $37^{\circ} \mathrm{C}$ for $24 \mathrm{~h}$.

\section{RESULTS AND DISCUSSION}

\section{Biosurfactant production in carbon sources}

In this experiment, glucose, sucrose, soya bean oil, palm oil and coconut oil were used as carbon sources in culture medium. Biosurfactant production was determined by biosurfactant activities, both in terms of surface-tension reduction and by oil displacement test. The results in Table 1 indicate 
Table 1 Various carbon sources on biosurfactant production by $W$. anomalus PY189.

\begin{tabular}{lcccc}
\hline $\begin{array}{l}\text { Carbon } \\
\text { source } \\
(4 \%)\end{array}$ & $\begin{array}{c}\text { Cell } \\
\text { dry weight } \\
(\mathrm{g} / \mathrm{l})\end{array}$ & $\begin{array}{c}\text { Surface } \\
\text { tension } \\
(\mathrm{mN} / \mathrm{m})\end{array}$ & $\begin{array}{c}\Delta \mathrm{ST} \\
(\mathrm{mN} / \mathrm{m})\end{array}$ & $\begin{array}{c}\text { Oil dis- } \\
\text { placement } \\
\left(\mathrm{cm}^{2}\right)\end{array}$ \\
\hline Glucose & $14.9 \pm 0.7$ & $44.3 \pm 0.5$ & 15.23 & $3.14 \pm 0.29$ \\
Sucrose & $10.4 \pm 0.8$ & $47.8 \pm 0.8$ & 13.67 & $2.72 \pm 0.26$ \\
Soya bean oil & $15.2 \pm 0.3$ & $38.9 \pm 0.6$ & 16.56 & $12.33 \pm 0.29$ \\
Palm oil & $14.8 \pm 0.3$ & $40.3 \pm 1.0$ & 10.33 & $6.3 \pm 1.0$ \\
Coconut oil & $6.8 \pm 0.7$ & $54.9 \pm 0.3$ & 9.14 & $0.25 \pm 0.14$ \\
\hline
\end{tabular}

Table 2 Various concentrations of soya bean oil on biosurfactant production by W. anomalus PY189.

\begin{tabular}{lcccc}
\hline $\begin{array}{l}\text { Soya bean } \\
\text { oil concen- } \\
\text { tration }(\%)\end{array}$ & $\begin{array}{c}\text { Cell } \\
\text { dry weight } \\
(\mathrm{g} / \mathrm{l})\end{array}$ & $\begin{array}{c}\text { Surface } \\
\text { tension } \\
(\mathrm{mN} / \mathrm{m})\end{array}$ & $\begin{array}{c}\Delta \mathrm{ST} \\
(\mathrm{mN} / \mathrm{m})\end{array}$ & $\begin{array}{c}\text { Oil dis- } \\
\text { placement } \\
\left(\mathrm{cm}^{2}\right)\end{array}$ \\
\hline 0 & $2.2 \pm 0.6$ & $55.8 \pm 0.6$ & 1.25 & $1.13 \pm 0.24$ \\
1 & $6.5 \pm 0.7$ & $49.2 \pm 0.8$ & 1.7 & $1.79 \pm 0.36$ \\
2 & $10.8 \pm 0.6$ & $46.2 \pm 0.5$ & 4.76 & $8.17 \pm 0.32$ \\
4 & $14.0 \pm 0.4$ & $37.6 \pm 0.7$ & 18.5 & $12.6 \pm 1.0$ \\
8 & $10.5 \pm 0.7$ & $38.8 \pm 0.3$ & 16.12 & $11.23 \pm 0.22$ \\
\hline
\end{tabular}

that the carbon source promoting the best biosurfactant production was soya bean oil. Using this carbon source, $W$. anomalus PY189 could produce $12.33 \mathrm{~cm}^{2}$ of oil displacement activity and reduced surface tension activity to $38.9 \mathrm{mN} / \mathrm{m}$ at 7 days of cultivation. The result in Table 2 suggested that $4 \%$ (v/v) soya bean oil was the most appropriate carbon source for biosurfactant production by PY189.

\section{Biosurfactant production nitrogen sources}

$\mathrm{NaNO}_{3}$ supported growth and biosurfactant production of the microorganism (Table 3 ). W. anomalus PY189 could produce the biosurfactant with the highest activity in the presence of $\mathrm{NaNO}_{3}$. Acidic nitrogen sources such as $\mathrm{NH}_{4} \mathrm{NO}_{3}$ and $\left(\mathrm{NH}_{4}\right)_{2} \mathrm{SO}_{4}$ reduced the culture $\mathrm{pH}$ from the initial value of 5.5 to about $3-4$, and yielded low biosurfactant production. The results in Table 4 suggest that $0.4 \%$ $(\mathrm{w} / \mathrm{v}) \mathrm{NaNO}_{3}$ was the most effective nitrogen source for biosurfactant production by W. anomalus PY189.

\section{Characterization of biosurfactants}

The dry crude extract was obtained at $0.57 \mathrm{~g} / 1$ from soy bean oil medium. The crude biosurfactant extract showed a CMC of $204 \mathrm{mg} / \mathrm{l}$. TLC analysis

Table 3 Various nitrogen sources on biosurfactant production by $W$. anomalus PY189.

\begin{tabular}{lcccc}
\hline $\begin{array}{l}\text { Nitrogen } \\
\text { source } \\
(0.4 \%)\end{array}$ & $\begin{array}{c}\text { Cell } \\
\text { dry weight } \\
(\mathrm{g} / \mathrm{l})\end{array}$ & $\begin{array}{c}\text { Surface } \\
\text { tension } \\
(\mathrm{mN} / \mathrm{m})\end{array}$ & $\begin{array}{c}\Delta \mathrm{ST} \\
(\mathrm{mN} / \mathrm{m})\end{array}$ & $\begin{array}{c}\text { Oil dis- } \\
\text { placement } \\
\left(\mathrm{cm}^{2}\right)\end{array}$ \\
\hline $\mathrm{NaNO}_{3}$ & $12.8 \pm 0.3$ & $37.7 \pm 0.7$ & 16.7 & $11.8 \pm 0.4$ \\
$\left(\mathrm{NH}_{4}\right)_{2} \mathrm{SO}_{4}$ & $10.7 \pm 0.3$ & $42.5 \pm 1.0$ & 12.5 & $9.8 \pm 0.5$ \\
$\mathrm{NH}_{4} \mathrm{NO}_{3}$ & $11.8 \pm 0.7$ & $40.8 \pm 0.4$ & 11.6 & $8.9 \pm 0.9$ \\
\hline
\end{tabular}

Table 4 Various nitrogen sources on biosurfactant production by $W$. anomalus PY189.

\begin{tabular}{lcccc}
\hline $\begin{array}{l}\mathrm{NaNO}_{3} \\
\text { concentra- } \\
\text { tion (\%) }\end{array}$ & $\begin{array}{c}\text { Oil dis- } \\
\text { placement } \\
\left(\mathrm{cm}^{2}\right)\end{array}$ & $\begin{array}{c}\text { Cell } \\
\text { dry weight } \\
(\mathrm{g} / \mathrm{l})\end{array}$ & $\begin{array}{c}\text { Surface } \\
\text { tension } \\
(\mathrm{mN} / \mathrm{m})\end{array}$ & $\begin{array}{c}\Delta \mathrm{ST} \\
(\mathrm{mN} / \mathrm{m})\end{array}$ \\
\hline 0 & $2.3 \pm 0.4$ & $42.5 \pm 0.5$ & 10.57 & $0.53 \pm 0.29$ \\
0.1 & $4.2 \pm 0.5$ & $40.2 \pm 0.6$ & 10.95 & $4.68 \pm 0.25$ \\
0.2 & $9.7 \pm 0.3$ & $39.6 \pm 0.8$ & 14.8 & $4.92 \pm 0.32$ \\
0.3 & $10.8 \pm 0.4$ & $40.3 \pm 1.1$ & 13.06 & $9.2 \pm 1.2$ \\
0.4 & $14.5 \pm 0.6$ & $36.5 \pm 0.3$ & 18.45 & $10.17 \pm 0.23$ \\
0.5 & $10.20 \pm 0.13$ & $38.8 \pm 0.6$ & 16.24 & $8.5 \pm 0.5$ \\
\hline
\end{tabular}

showed that all the iodine positive spots but F2 and F3 were positive for Molisch reagent staining test (Fig. 1). The positive spots obtained from the iodine and Molisch reagent tests for crude extract indicated that biosurfactant produced by PY189 is of glycolipid type.

\section{Emulsification of lemongrass oil}

Emulsions prepared from various ratios of lemongrass oil in $20 \mathrm{mg} / \mathrm{dl}$ maltodextrin solution containing $0.6-1 \%(\mathrm{w} / \mathrm{v})$ crude biosurfactant were used to determine emulsion stability and average volume of the oil droplet. Only the emulsion containing $0.6 \%$ crude biosurfactant was unstable and separation of oil was observed after homogenization. All the resulting oil-in-water $(\mathrm{O} / \mathrm{W})$ emulsion appeared milky white-yellow colour and had low viscosity. Volume average diameter, $D[4,3]$, of lemongrass oil droplets in emulsion with different biosurfactant concentrations and oil:maltodextrin ratios are compared in Table 5. The results suggested that an increase in biosurfactant concentration or a reduction in oil:maltodextrin ratio led to a decrease in oil droplet size in emulsion. The optimal concentration of biosurfactant for spray-drying was therefore determined to be $1 \%$ for oil:maltodextrin $0.15: 1$ and 0.2:1 levels.

\section{Powder morphology and particle size analysis}

After the spray drying process, the spray-dried microcapsules became dry powder with light yellow colour. The outer topographies of spray-dried lemongrass oil microcapsule were determined by SEM (Fig. 2). The spray-dried powder was almost spherical and had small holes dispersing on their wall. The particle surface was smooth. When the microcapsules were cross-sectioned, it could be observed that the core material was in the form of small droplets embedded in the wall matrix layer (Fig. 3). The average particle sizes and microencapsulation efficiency of lemon grass oil microcapsule prepared with oil:maltodextrin ratios of $0.2: 1$ and 

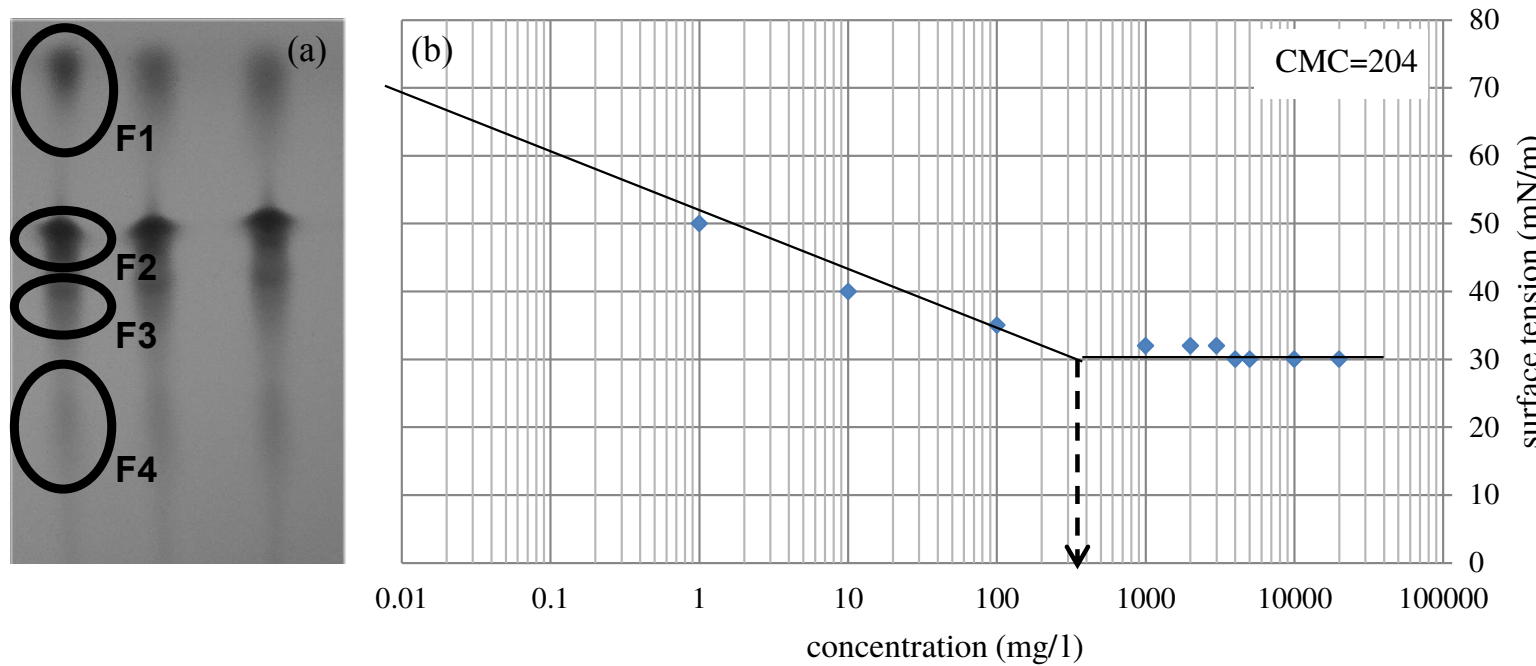

Fig. 1 (a) TLC analysis visualized with iodine vapour of biosurfactant produced by W. anomalus PY189. (b) CMC of biosurfactant produced by W. anomalus PY189.

Table 5 Volume average diameter $(\mu \mathrm{m})$ of lemongrass oil emulsion.

\begin{tabular}{lccc}
\hline Biosurfactant & \multicolumn{3}{c}{ Oil:maltodextrin } \\
\cline { 2 - 4 } concentration (\%) & $0.1: 1$ & $0.15: 1$ & $0.2: 1$ \\
\hline 0.6 & $\mathrm{ND}$ & $\mathrm{ND}$ & $\mathrm{ND}$ \\
0.8 & 10.2 & 11.5 & 13.7 \\
1.0 & 4.1 & 6.0 & 8.0 \\
\hline
\end{tabular}

ND: not determined due to instability.

Table 6 MIC of lemongrass oil and microcapsules.

\begin{tabular}{lccc}
\hline Samples & $\begin{array}{c}\text { Escherichia } \\
\text { coli }\end{array}$ & $\begin{array}{c}\text { Staphylococcus } \\
\text { aureus }\end{array}$ & $\begin{array}{c}\text { Salmonella } \\
\text { sp. }\end{array}$ \\
\hline $\begin{array}{l}\text { Lemongrass oil } \\
\text { (\% v/v) }\end{array}$ & 0.0625 & 0.0625 & 0.125 \\
$\begin{array}{l}\text { Microcapsules } \\
(\% \mathrm{w} / \mathrm{v})\end{array}$ & 5 & 5 & 5 \\
\hline
\end{tabular}

$0.15: 1$ were $9.2 \pm 0.8 \mu \mathrm{m}$ and $10.8 \pm 0.9 \mu \mathrm{m}$, and $48 \%$ and $52 \%$, respectively.

\section{Minimum inhibitory concentration}

MIC of lemongrass oil and its microcapsules prepared from 0.2:1 oil-to-maltodextrin ratio are compared in Table 6. The results from agar dilution method suggested that the microcapsule containing lemongrass oil was capable of inhibiting growth of all three pathogens E. coli, S. aureus and Salmonella sp. at $5 \%(w / v)$.

\section{CONCLUSIONS}

W. anomalus PY189 could produce biosurfactant when cultured in production medium containing (w/v): $0.02 \% \mathrm{KH}_{2} \mathrm{PO}_{4}, 0.02 \% \mathrm{MgSO}_{4} \cdot 7 \mathrm{H}_{2} \mathrm{O}, 0.1 \%$

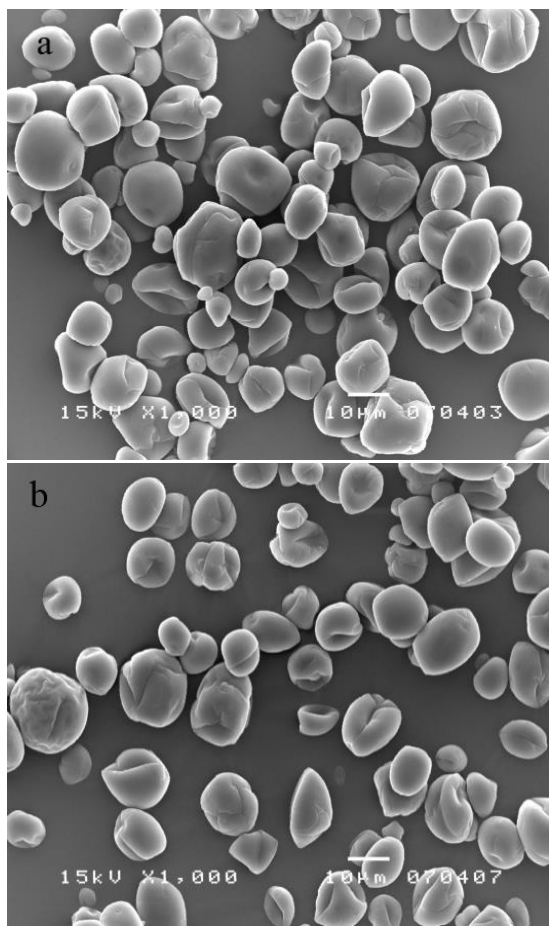

Fig. 2 SEM images of spray-dried lemongrass oil microcapsules prepared from emulsion containing oil:maltodextrin ratios of (a) $0.2: 1$ and (b) $0.15: 1$. Emulsion was prepared using 1\% biosurfactant in each case.

yeast extract, $0.4 \% \mathrm{NaNO}_{3}$ and $4 \%(\mathrm{v} / \mathrm{v})$ soya bean oil. The PY189 could produce the biosurfactant having $10.17 \mathrm{~cm}^{2}$ of oil displacement activity and 

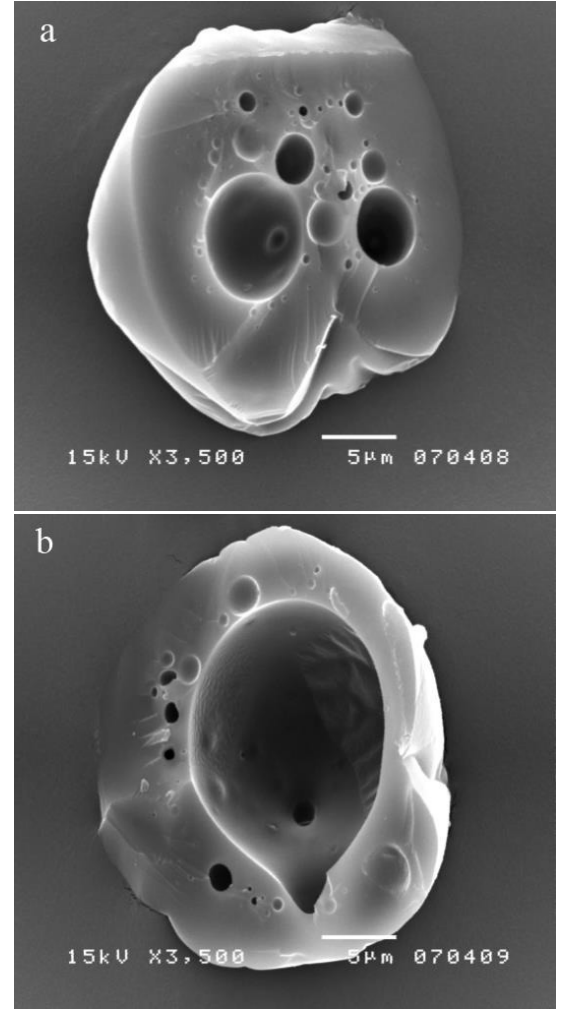

Fig. 3 SEM cross-sectioned images of spray-dried lemongrass oil microcapsules prepared from emulsion containing oil:maltodextrin ratio of (a) $0.2: 1$ and (b) $0.15: 1$.

reducing surface tension activity to $36.5 \mathrm{mN} / \mathrm{m}$ at 7 days of cultivation and in its crude form. The crude biosurfactant showed a CMC of $204 \mathrm{mg} / 1$. TLC analysis revealed that biosurfactant produced by $W$. anomalus PY189 is of glycolipid type. The emulsions prepared from lemongrass oil in $20 \mathrm{mg} / \mathrm{dl}$ maltodextrin solution and $0.8 \%$ and $1 \%$ biosurfactant concentrations were stable for at least $24 \mathrm{~h}$ after preparation. Lemongrass oil microcapsules produced by spray drying technique exhibited microbial inhibition activity against $E$. coli, $S$. aureus and Salmonella sp. at 5\% (w/v) concentration.

\section{Future perspective}

Biosurfactants alter microbial environments by their surface activity and antimicrobial activity that could help ensuring dominance of the habitat in nature by species such as $W$. anomalus ${ }^{20}$. Further understanding of this observation may lead to new means to enhance production of biosurfactants; for instance, a co-culture of $W$. anomalus with some ally or competitor microbe that triggers enhanced production of antimicrobial biosurfactant ${ }^{21,22}$. W. anomalus is known to have robust stress biology, giving rise to the possibility that the various activities of solutes, such as osmotic stress, water-activity reduction, and chaotropicity might enhance production of biosurfactant ${ }^{5}$. Microbial stress biology could be utilized to enhance microbial behaviour, and the production of microbial metabolites, for biotechnological purposes ${ }^{23-26}$. Further work is needed to explore additional ways in which biosurfactant production by $W$. anomalus PY189 can be better optimized.

Acknowledgements: This study was supported by the integration project of "Innovations for the improvement of food safety and food quality for new world economy," the government research budget of Thailand and Chulalongkorn University. The authors appreciate valuable suggestions from the referees, which are very helpful in the improvement of this manuscript.

\section{REFERENCES}

1. Banat IM, Makkar RS, Cameotra SS (2000) Potential commercial applications of microbial surfactants. Appl Microbiol Biotechnol 53, 495-508.

2. Nitschke M, Pastore GM (2006) Production and properties of a surfactant obtained from Bacillus subtilis grown on cassava wastewater. Bioresour Tech 97, 336-41.

3. Rahman PKSM, Gakpe E (2008) Production, characterization and applications of biosurfactantsReview. Biotechnology 7, 360-70.

4. Kurtzman CP, Robnett CJ, Basehoar-Powers E (2008) Phylogeneic relationships among species of Pichia, Issatchenkia and Williopsis determined from multigene phylogenetic analysis, and the proposal of Barnettozyma gen. nov., Lindnera gen. nov. and Wickerhamomyces gen. nov. FEMS Yeast Res 8, 939-54.

5. Walker GM (2011) Pichia anomala: cell physiology and biotechnology relative to other yeasts. Antonie Leeuwenhoek 99, 25-34.

6. Magliani W, Conti S, Salati A, Arseni S, Ravanetti L, Frazzi R, Polonelli L (2009) Biotechnological approaches to the production of idiotypic vaccines and antiidiotypic antibiotics. Curr Pharmaceut Biotechnol 4, 91-7.

7. Passoth V, Olstorpe M, Schnürer J (2011) Past, present and future research directions with Pichia anomala. Antonie Leeuwenhoek 99, 121-5.

8. Mo E-K, Kang H-J, Lee C-T, Xu B-J, Kim J-H, Wang Q-J, Kim J-C, Sung C-K (2003) Identification of phenylethyl alcohol and other volatile flavor compounds from yeasts, Pichia farinosa SKM-1, Pichia anomala SKM-T, and Galactomyces geotrichum SJM59. J Microbiol Biotechnol 13, 800-8.

9. Swangkeaw J, Vichitphan S, Butzke CE, Vichitphan K (2009) The characteristics of a novel Pichia anomala 
$\beta$-glucosidase with potentially aroma-enhancing capabilities in wine. Ann Microbiol 59, 335-43.

10. Thaniyavarn J, Chianguthai T, Sangvanich P, Roongsawang N, Washio K, Morikawa M, Thaniyavarn S (2008) Production of sophorolipid biosurfactant by Pichia anomala. Biosci Biotechnol Biochem 72, 2061-8.

11. Shepherd R, Rockey J, Sutherland IW, Roller S (1995) Novel bioemulsifiers from microorganisms for use in foods. J Biotechnol 40, 207-17.

12. Salvia-Trujillo L, Rojas-Graü A, Soliva-Fortuny R, Martín-Belloso O (2013) Physicochemical characterization of lemongrass essential oil-alginate nanoemulsions: effect of ultrasound processing parameters. Food Bioproc Tech 6, 2439-46.

13. Saggiorato AG, Gaio I, Treichel H, de Oliveira D, Cichoski AJ, Cansian RL (2009) Antifungal activity of basil essential oil (Ocimum basilicum L.): evaluation in vitro and on an Italian-type sausage surface. Food Bioproc Tech 5, 378-84.

14. Burt S (2004) Essential oils: their antibacterial properties and potential applications in foods-a review. Int $J$ Food Microbiol 94, 223-53.

15. Leimann FV, Gonçalves OH, Machado RAF, Bolzan A (2009) Antimicrobial activity of microencapsulated lemongrass essential oil and the effect of experimental parameters on microcapsules size and morphology. Mater Sci Eng 29, 430-6.

16. Techaoei S, Leelapornpisid P, Santiarwarn D, Lumyong S (2007) Preliminary screening of biosurfactant producing microorganisms isolated from hot spring and garages in northern Thailand. KMITL Sci Tech $J$ 7, 38-43.

17. Macy R (1935) Surface tension by the ring method. Applicability of the du Nouy apparatus. J Chem Educ 12, 573-8.

18. Baeurle SA, Kroener J (2004) Modeling effective interactions of micellar aggregates of ionic surfactants with the Gauss-Core potential. J Math Chem 36, 409-21.

19. Hogan SA, McNamee BF, O'Riordan ED, O'Sullivan M (2001) Emulsification and microencapsulation properties of sodium caseinate/carbohydrate blends. Int J Dairy Tech 11, 137-44.

20. Cray JA, Bell ANW, Bhaganna P, Mswaka AY, Timson DJ, Hallsworth JE (2013) The biology of habitat dominance; can microbes behave as weeds? Microb Biotechnol 6, 453-92.

21. Kwasiborski A, Bajji M, Renaut J, Delaplace P, Jijakli MH (2014) Identification of metabolic pathways expressed by Pichia anomala Kh6 in the presence of the pathogen Botrytis cinerea on apple: new possible targets for biocontrol improvement. PLOS ONE 9 , e91434.

22. Jagmann N, Philipp B (2014) Design of synthetic microbial communities for biotechnological production processes. J Biotechnol 184, 209-18.
23. Vanacloig-Pedros E, Bets-Plasencia C, Pascual-Ahuir A, Proft M (2015) Coordinated gene regulation in the initial phase of salt stress adaptation. $J$ Biol Chem 290, 10163-75.

24. Cray JA, Stevenson A, Ball P, Bankar SB, Eleutherio ECA, Ezeji TC, Singhal RS, Thevelein JM, Timson DJ, Hallsworth JE (2015) Chaotropicity: a key factor in product tolerance of biofuel-producing microorganisms. Curr Opin Biotechnol 33, 228-59.

25. Yang LB, Zhan XB, Zheng ZY, Wu JR, Gao MJ, Lin CC (2014) A novel osmotic pressure control fed-batch fermentation strategy for improvement of erythritol production by Yarrowia lipolytica from glycerol. Bioresour Tech 151, 120-7.

26. Westman JO, Franzén CJ (2015) Current progress in high cell density yeast bioprocesses for bioethanol production. Biotechnol J 10, 1185-95. 